Journal Club

Editor's Note: These short, critical reviews of recent papers in the Journal, written exclusively by graduate students or postdoctoral fellows, are intended to summarize the important findings of the paper and provide additional insight and commentary. For more information on the format and purpose of the Journal Club, please see http://www.jneurosci.org/misc/ifa_features.shtml.

\title{
Social Stress-Induced Alterations in CRF Signaling in the VTA Facilitate the Emergence of Addiction-like Behavior
}

\author{
๑Brendan J. Tunstall ${ }^{\star}$ and $@$ Stephanie A. Carmack ${ }^{\star}$ \\ National Institute on Drug Abuse, National Institutes of Health, Baltimore, Maryland 21224 \\ Review of Holly et al.
}

Stress increases the vulnerability to addiction in humans (for review, see Sinha, 2008). In preclinical studies, stressors can enhance drug self-administration and induce relapse (Miczek et al., 2008; Mantsch et al., 2016). The brain region-specific molecular mechanisms that mediate the interaction between stress and cocaine selfadministration are multifaceted, and their elucidation is a work in progress ( $\mathrm{Lu}$ et al., 2003; Miczek et al., 2008).

One potential mediator is corticotropinreleasing factor (CRF), a neuropeptide associated both with behavioral and physiological responses to stress (Vale et al., 1981; Sutton et al., 1982) and with escalation of drug self-administration (Koob et al., 2014). CRF binds to $\mathrm{CRF}_{1}$ and $\mathrm{CRF}_{2}$ receptors and acts on the hypothalamic-pituitary-adrenal axis, as well as extrahypothalamic areas, including the amygdala, bed nucleus of stria terminalis, and ventral tegmental area (VTA) (Bale and Vale, 2004). CRF signaling in the VTA is a particularly compelling candidate mechanism because drugs of abuse and stressful/aversive stimuli generate simi-

Received June 6, 2016; revised July 15, 2016; accepted July 19, 2016.

This work was supported by the National Institute on Drug Abuse, Intramural Research Program. We thank Drs. Leandro Vendruscolo, George Koob, and Yavin Shaham for helpful comments on the manuscript; and Michael Arends for editorial assistance.

The authors declare no competing financial interests.

*B.J.T. and S.A.C. contributed equally to this work.

Correspondence should be addressed to Dr. Brendan J. Tunstall, National Institute on Drug Abuse, Intramural Research Program, 251 Bayview Blvd, BRC 08A406.17, Baltimore, MD 21224. E-mail: brendan.tunstall@nih.gov.

DOI:10.1523/JNEUROSCI.1815-16.2016

Copyright $\odot 2016$ the authors $\quad 0270-6474 / 16 / 368780-03 \$ 15.00 / 0$ lar activation in the VTA. Furthermore, recent work has shown that $\mathrm{CRF}_{1}$ and $\mathrm{CRF}_{2}$ receptors are involved in the VTA response to social stress (Holly et al., 2015) and that this response facilitates later cocaine "binge" self-administration (i.e., increased cocaine taking when rats are given $24 \mathrm{~h}$ of unlimited drug access) (Boyson et al., 2014).

A recent study in The Journal of Neuroscience by Holly et al. (2016) tested the hypothesis that stress-induced CRF signaling in the VTA drives cocaine addiction-like behaviors in a VTA subregion and CRF receptor subtype-specific manner. The VTA is a morphologically and functionally heterogeneous structure (Ikemoto, 2007), with the posterior (pVTA) and anterior (aVTA) regions differentially required both in the case of reinforcement (e.g., drugs of abuse) and aversion (e.g., footshock) (Holly and Miczek, 2016). Additionally, there are conflicting reports in the literature on the involvement of specific CRF receptor subtypes within the VTA in the interaction between stress and cocaine addiction-like behaviors. For example, some have reported that $\mathrm{CRF}_{1}$, but not $\mathrm{CRF}_{2}$, receptors are required for stress-induced reinstatement of cocaine seeking (Blacktop et al., 2011), whereas others have found the opposite (Wang et al., 2007). These discrepant findings may be due to functional heterogeneity of CRF signaling in the VTA along the anterior/posterior axis.

In Experiment 1, Holly et al. (2016) used in vivo microdialysis to investigate how VTA CRF levels change over the course of repeated exposure to social defeat stress. Dur- ing the first session, CRF levels in the pVTA, but not aVTA, increased dramatically during stress and remained elevated afterward. By the fourth session, however, CRF in the aVTA was significantly elevated during stress, whereas pVTA CRF decreased following stress. Furthermore, both the aVTA and pVTA had increased basal CRF release by the fourth session of social stress. These results show that the CRF response in the VTA to social stress is dynamically regulated (ON/OFF changes in signaling within $1 \mathrm{~h}$ ), enduring (higher basal CRF after repeated stress), and adjusted in a subregion-specific manner over repeated trials (the aVTA appears to be recruited with repeated episodes, whereas the pVTA response is blunted).

In Experiment 2, the authors demonstrated that socially stressed rats administered significantly more cocaine during a $24 \mathrm{~h}$ binge session compared with nonstressed controls. The effect of stress was notably long-lasting, as the self-administration test was conducted at least $30 \mathrm{~d}$ after stress. The authors observed a double dissociation between the requirements for specific CRF receptor subtypes along the anterior/posterior VTA axis. $\mathrm{CRF}_{1}$ receptors in the $\mathrm{pVTA}$, but not aVTA, and $\mathrm{CRF}_{2}$ receptors in the aVTA, but not pVTA, were necessary for increased cocaine intake in stressed rats.

In Experiment 3, the authors showed that persistent changes in VTA CRF signaling in previously stressed rats are necessary for long-term stress-induced facilitation of cocaine seeking. Similar to Experiment 2, $\mathrm{CRF}_{1}$ receptors in the $\mathrm{pVTA}$, but not aVTA, and $\mathrm{CRF}_{2}$ receptors in the aVTA, but not 
pVTA, were required for increased cocaine seeking following $15 \mathrm{~d}$ of cocaine abstinence. Previously stressed rats had enhanced tonic pVTA and aVTA CRF signaling compared with nonstressed groups, immediately before and throughout the cocaine-seeking test. Interestingly, neither stressed nor nonstressed rats exhibited phasic changes in VTA CRF during the test. The enhanced cocaine-seeking behavior observed in previously stressed rats may reflect a stable, persistent state mediated by chronically elevated VTA CRF signaling induced by stress/cocaine exposure rather than one that was activated in response to the drugseeking test. Consistent with the notion that propensity to seek cocaine is a stable state, in a choice-reinstatement procedure, a strong correlation was found between preference for previously cocaine- and food-reinforced levers over the course of extinction responding and during reinstatement tests that were conducted in subsequent weeks (Tunstall and Kearns, 2014).

The findings of Holly et al. (2016) raise the question: how does increased CRF release during and after stress lead to increased cocaine taking and seeking? CRF is critically involved in compensatory opponent or "rebound" mechanisms that are engaged in an effort to counteract the effects of cocaine following intense/prolonged drug self-administration (Koob and Le Moal, 2008). Enhanced CRF signaling contributes to the aversive state experienced in cocaine withdrawal (opposite the positive hedonic state experienced during drug intoxication), which may motivate a subject to seek and take more cocaine to alleviate negative affect (i.e., negative reinforcement). We hypothesize that, when subjects with already elevated CRF levels (i.e., previously stressed rats) self-administer sufficient amounts of cocaine, cessation of cocaine taking produces an augmented aversive state, which facilitates addiction-like behavior.

Enhanced CRF could contribute to an aversive state driving addiction-like behaviors via modulation of mesolimbic dopamine function. CRF can modulate VTA dopamine neurons (Ungless et al., 2003; Wang et al., 2005) and can enhance dopamine signaling in the nucleus accumbens, similarly to drugs of abuse (Deutch and Roth, 1990). It is possible that CRF could sensitize mesolimbic dopamine function, which would be expected to enhance the positive rewarding properties of cocaine. However, VTA CRF can also decrease dopamine release in the nucleus accumbens, depending on the upstream input to the VTA (Wanat et al., 2013; Grieder et al., 2014). Furthermore, CRF injected intracerebroventricularly can decrease brain stimula- tion reward (Macey et al., 2000). It remains unclear whether altered CRF signaling in the VTA observed by Holly and Miczek (2016) affected VTA dopamine release or mesolimbic reward function. It is also possible that enhanced CRF contributes to an augmented negative affective state through dopamineindependent, prostress effects. Critical experiments to extend the present results would be to assess alterations in VTA dopamine signaling (e.g., using in vivo microdialysis) and mesolimbic reward function (e.g., using intracranial self-stimulation) during the critical stages of the present experimental design, particularly following binge-access to cocaine and during cocaine abstinence. We predict that previously stressed rats would be more hypohedonic and display more blunted mesolimbic dopamine function than nonstressed controls following this cocaine exposure.

The role of CRF signaling during repeated social-defeat stress and later cocaine self-administration behavior is compelling. Future experiments could directly test the hypothesis that repeated social stress strengthens opponent processes activated by cocaine. This could be achieved by comparing previously nonstressed versus stressed groups in the strength of their response to the delayed, aversive effects of cocaine injections (Su et al., 2013; Zhou et al., 2014). If stress sensitizes the compensatory mechanisms activated by cocaine (i.e., CRF signaling), we would expect previously stressed rats to demonstrate an enhanced aversion response. The contracted timescale of a place aversion design may also be useful in future experiments designed to explore neurobiological mechanisms that may buffer against or facilitate the CRF response to stress. For example, oxytocin is a candidate buffer mechanism, having antistress properties that may be mediated in part by interference with stress-induced CRF transcription (Jurek et al., 2015). In contrast, vasopressin is a candidate facilitation mechanism, as vasopressin is known to be potently synergistic with CRF in causing release of adrenocorticotropic hormone (Gillies et al., 1982). Vasopressin has also been shown to be upregulated in response to repeated stress, resulting in increased colocalization of vasopressin in CRF neurons in the median eminence (de Goeij et al., 1991) and paraventricular nucleus (de Goeij et al., 1992).

Finally, if we consider cocaine self-administration, particularly the negative emotional experience associated with the engagement of opponent processes, as a stressful experience, then we may consider the results of Holly et al. (2016) as a charac- terization of the long-lasting "priming" of a stress signaling system. In the case of social defeat, we may observe the effect of enhanced stress signaling through enhanced motivation to avoid or escape a stressful situation. In the case of cocaine self-administration, we would expect the effects of social stress to combine with opponent processes stress-signaling, further enhancing the motivation to seek and self-administer cocaine.

\section{References}

Bale TL, Vale WW (2004) CRF and CRF receptors: role in stress responsivity and other behaviors. Annu Rev Pharm Toxicol 44:525-557. CrossRef Medline

Blacktop JM, Seubert C, Baker DA, Ferda N, Lee G, Graf EN, Mantsch JR (2011) Augmented cocaine seeking in response to stress or CRF delivered into the ventral tegmental area following long-access self-administration is mediated by CRF receptor type 1 but not CRF receptor type 2. J Neurosci 31:11396-11403. CrossRef Medline

Boyson CO, Holly EN, Shimamoto A, AlbrechetSouza L, Weiner LA, DeBold JF, Miczek KA (2014) Social stress and CRF-dopamine interactions in the VTA: role in long-term escalation of cocaine self-administration. J Neurosci 34:6659-6667. CrossRef Medline

de Goeij DC, Kvetnansky R, Whitnall MH, Jezova D, Berkenbosch F, Tilders FJ (1991) Repeated stress-induced activation of corticotropin-releasing factor neurons enhances vasopressin stores and colocalization with corticotropin-releasing factor in the median eminence of rats. Neuroendocrinology 53:150-159. Medline

de Goeij DC, Jezova D, Tilders FJ (1992) Repeated stress enhances vasopressin synthesis in corticotropin releasing factor neurons in the paraventricular nucleus. Brain Res 577: 165-168. CrossRef Medline

Deutch AY, Roth RH (1990) The determinants of stress-induced activation of the prefrontal cortical dopamine system. Prog Brain Res 85: 367-403. CrossRef Medline

Gillies GE, Linton EA, Lowry PJ (1982) Corticotropin releasing activity of the new CRF is potentiated several times by vasopressin. Nature 299:355-357. CrossRef Medline

Grieder TE, Herman MA, Contet C, Tan LA, Vargas-Perez H, Cohen A, Chwalek M, MaalBared G, Freiling J, Schlosburg JE, Clarke L, Crawford E, Koebel P, Repunte-Canonigo V, Sanna PP, Tapper AR, Roberto M, Kieffer BL, Sawchenko PE, Koob GF, et al. (2014) VTA CRF neurons mediate the aversive effects of nicotine withdrawal and promote intake escalation. Nat Neurosci 17:1751-1758. CrossRef Medline

Holly EN, Miczek KA (2016) Ventral tegmental area dopamine revisited: effects of acute and repeated stress. Psychopharmacology 233: 163-186. CrossRef Medline

Holly EN, DeBold JF, Miczek KA (2015) Increased mesocorticolimbic dopamine during acute and repeated social defeat stress: modulation by corticotropin releasing factor receptors in the ventral tegmental area. Psychopharmacology 232:44694479. CrossRef Medline 
Holly EN, Boyson CO, Montagud-Romero S, Stein DJ, Gobrogge KL, DeBold JF, Miczek KA (2016) Episodic social stress-escalated cocaine self-administration: role of phasic and tonic corticotropin releasing factor in the anterior and posterior ventral tegmental area. J Neurosci 36:4093-4105. CrossRef Medline

Ikemoto S (2007) Dopamine reward circuitry: two projection systems from the ventral midbrain to the nucleus accumbens-olfactory tubercle complex. Brain Res Rev 56:27-78. CrossRef Medline

Jurek B, Slattery DA, Hiraoka Y, Liu Y, Nishimori K, Aguilera G, Neumann ID, van den Burg EH (2015) Oxytocin regulates stress-induced Crf gene transcription through CREB-regulated transcription coactivator 3. J Neurosci 35: 12248-12260. CrossRef Medline

Koob GF, Le Moal M (2008) Neurobiological mechanisms for opponent motivational processes in addiction. Philos Trans R Soc Lond B Biol Sci 363:3113-3123. CrossRef Medline

Koob GF, Buck CL, Cohen A, Edwards S, Park PE, Schlosburg JE, Schmeichel B, Vendruscolo LF, Wade CL, Whitfield TW Jr, George O (2014) Addiction as a stress surfeit disorder. Neuropharmacology 76:370-382. CrossRef Medline

Lu L, Shepard JD, Hall FS, Shaham Y (2003) Effect of environmental stressors on opiate and psychostimulant reinforcement, reinstatement and discrimination in rats: a review. Neurosci Biobehav Rev 27:457-491. CrossRef Medline
Macey DJ, Koob GF, Markou A (2000) CRF and urocortin decreased brain stimulation reward in the rat: reversal by a CRF receptor antagonist. Brain Res 866:82-91. CrossRef Medline

Mantsch JR, Baker DA, Funk D, Lê AD, Shaham Y (2016) Stress-induced reinstatement of drug seeking: 20 years of progress. Neuropsychopharmacology 41:335-356. CrossRef Medline

Miczek KA, Yap JJ, Covington HE 3rd (2008) Social stress, therapeutics and drug abuse: preclinical models of escalated and depressed intake. Pharmacol Ther 120:102-128. CrossRef Medline

Sinha R (2008) Chronic stress, drug use, and vulnerability to addiction. Ann N Y Acad Sci 1141:105-130. CrossRef Medline

Su ZI, Santoostaroam A, Wenzel J, Ettenberg A (2013) On the persistence of cocaine-induced place preferences and aversions in rats. Psychopharmacology 229:115-123. CrossRef Medline

Sutton RE, Koob GF, Le Moal M, Rivier J, Vale W (1982) Corticotropin releasing factor produces behavioural activation in rats. Nature 297:331-333. CrossRef Medline

Tunstall BJ, Kearns DN (2014) Reinstatement in a cocaine versus food choice situation: reversal of preference between drug and non-drug rewards. Addict Biol 19:838-848. CrossRef Medline

Ungless MA, Singh V, Crowder TL, Yaka R, Ron D, Bonci A (2003) Corticotropin-releasing factor requires CRF binding protein to potentiate NMDA receptors via CRF receptor
2 in dopamine neurons. Neuron 39:401407. CrossRef Medline

Vale W, Spiess J, Rivier C, Rivier J (1981) Characterization of a 41-residue ovine hypothalamic peptide that stimulates secretion of corticotropin and beta-endorphin. Science 213:1394-1397. CrossRef Medline

Wanat MJ, Bonci A, Phillips PE (2013) CRF acts in the midbrain to attenuate accumbens dopamine release to rewards but not their predictors. Nat Neurosci 16:383-385. CrossRef Medline

Wang B, Shaham Y, Zitzman D, Azari S, Wise RA, You ZB (2005) Cocaine experience establishes control of midbrain glutamate and dopamine by corticotropin-releasing factor: a role in stress-induced relapse to drug seeking. J Neurosci 25:5389-5396. CrossRef Medline

Wang B, You ZB, Rice KC, Wise RA (2007) Stress-induced relapse to cocaine seeking: roles for the CRF2 receptor and CRF-binding protein in the ventral tegmental area of the rat. Psychopharmacology 193:283-294. CrossRef Medline

Zhou Y, Litvin Y, Pfaff D, Kreek M (2014) Involvement of KOP-r in cocaine withdrawal-induced conditioned place aversion in rats. Drug Alcohol Depend 140:e250. CrossRef 